\title{
A ROMAN SITE IN THE SÁRVÍZ RIVER VALLEY (PANNONIA INFERIOR)
}

\author{
AGNIESZKA TOMAS*-ZITA KIS** \\ *Institute of Archaeology, University of Warsaw, \\ ul. Krakowskie Przedmieście 26/28, 00-927 Warszawa, Poland \\ Email: agnieszka.tomas@uw.edu.pl \\ **Eötvös Loránd University, Múzeum krt. 4/b, \\ H-1088 Budapest, Hungary \\ Email: zitus.kis@gmail.com
}

\begin{abstract}
In October 2012 the workshop entitled "Reading Past and Present Landscapes in Central Europe" was held in Hungary. During the workshop, which was focused on exchanging ideas and experience concerning remote sensing methods of detection and registering archaeological sites, a large Roman site near the village of Sárbogárd in Nagyhörcsökpuszta was detected. The area of the site, its location, and the finds suggest that it could have played an important role in the region. This paper presents the results obtained from geophysical prospection and field walking, as well as the results of pottery analysis.
\end{abstract}

Keywords: Roman settlement, Pannonia inferior, geophysical prospection, field walking methods, Roman pottery finds

The area of research is placed in Fejér county (Hungary) which during the period of Roman rule belonged to the provincial interior of Lower Pannonia (Fig. 1). ${ }^{1}$ Its location was quite convenient for settlement; it was placed not far from the road connecting the military fort, later an important municipality of Gorsium with another crucial town of Sopianae. ${ }^{2}$ The site is situated at the inner edge of a wide valley of the Sárvíz river, on a wide plateau at 127-129 m a.s.l., sloping westwards, to the height of $107 \mathrm{~m}$ a.s.l., towards the Lóki stream (Fig. 2, 3), c. $8 \mathrm{~km}$ to the north from the present-day village of Sárbogárd.

\section{THE ANALYSIS OF DATA OBTAINED FROM THE GEOPHYSICAL SURVEY AND FIELDWALKING ${ }^{3}$}

The basis for the intensive field walking was a $100 \times 100$ metre virtual grid projected over the investigated area. The field survey was conducted by groups of four, walking parallel with each other along the N-S axis in 25 metre transects, covering the whole sample area. The spatial position of each artefact found on the field was recorded by GPS. ${ }^{4}$ The spread of finds dated to the Roman period covers the area some tens of hectares, with several concentrations. Two places situated at a distance of ca. $550 \mathrm{~m}$ from each other were rich in remains of building material (bricks, roof tiles, etc.). These two places (numbered as A and B) have been chosen for more detailed,

\footnotetext{
${ }^{1}$ G. MesterháZy-M. Stibrányi 2013 (e-journal available at http://www.hungarianarchaeology.hu/); TOMAS-JAWORSKI 2013, $171-176$.

${ }^{2}$ It. Ant. 264; SoPRONi 1980, 209, fig. 6 and 214.

${ }^{3}$ The fieldwalking survey was conducted and elaborated by G. Mesterházy, who was kind to share with the results some precious observations. The geophysical prospection was conducted and
}

elaborated by M. Jaworski, P. Wroniecki (PL) and M. Krajňák from the Comenius University in Bratislava (SK), whom we would like to thank. The authors of the present paper were invited to the project for consulting the Roman remains.

${ }^{4}$ Mesterházy-Stibrányi 2013; Mesterházy 2013 (in 


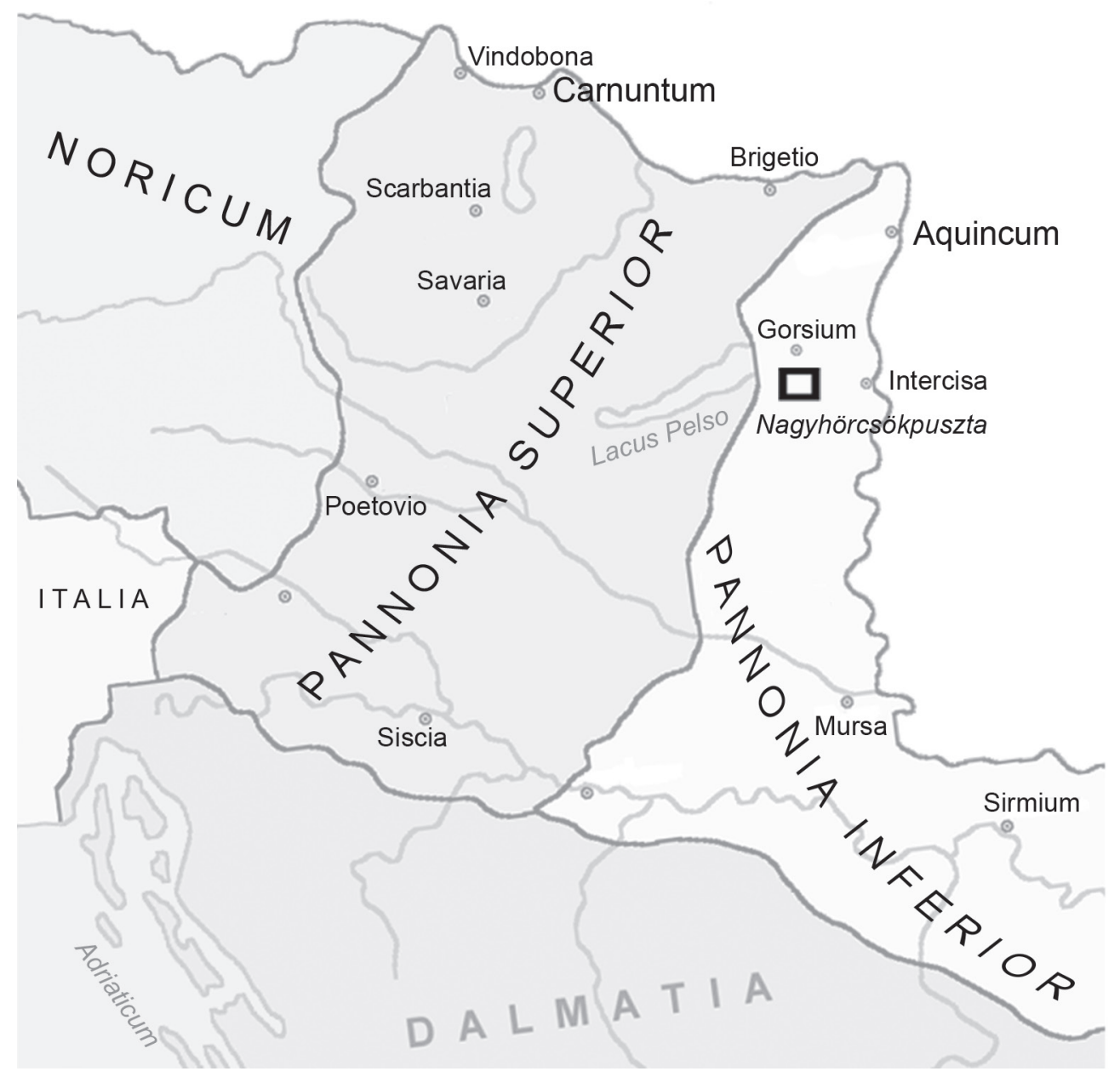

Fig. 1. Roman Pannonia and the location of the investigated area (by A. Tomas)

geophysical (magnetic) investigation (Fig. 4) with a fluxgate gradiometer Bartington Grad 601-Dual. The geophysically studied area covered 19200 sq. m, with two surveyed fields of 9600 sq. m $(80 \times 120 \mathrm{~m})$ each (Fig. 4).

Area A constitutes a part of the site disturbed by the accumulated linear disturbances (running SW-NE), resulting from ploughing and planting which can interfere with the reading of the results (Fig. 5). However, the image obtained from the geophysical survey shows two long parallel anomalies (over $100 \mathrm{~m}$ ) extended on the axis SW-NE, but slightly deviating from northwards. Another perpendicular anomaly is running NW-SE. The long anomalies may be traces of constructions (walls? fencing?). Numerous perpendicular anomalies on their both sides create square outlines, possibly rooms. One line oriented NW-SE is inclined ca. 30 degrees from the others. As it is probably not related with the above mentioned anomalies, we can deduce that it is a trace of either some infrascructural construction (e.g. an aquaduct) or another phase of construction with a changed orientation. Almost nothing we can say about big dipole anomalies visible in the central part of the investigated area (fireplaces?). The whole place A is not as rich in pottery shards as the area around place B, but fragments of bricks and roof tiles, as well as ceramic water supply pipes have been registered there.

The image obtained through geophysical studies in area B clearly indicates a parallel linear anomalies over a length of $100 \mathrm{~m}$ (Fig. 5). Due to the fact that the investigated part of the whole complex is relatively small, it is difficult to determine which part of the building (or buildings) we are dealing with. Empty square shape with adjacent rooms resembles a courtyard surrounded by a fence. Regular perpendicular and parallel linear anomalies may be the outlines of the courtyard, long corridor, and surrounding rooms as it is in many Roman villa-type es- 


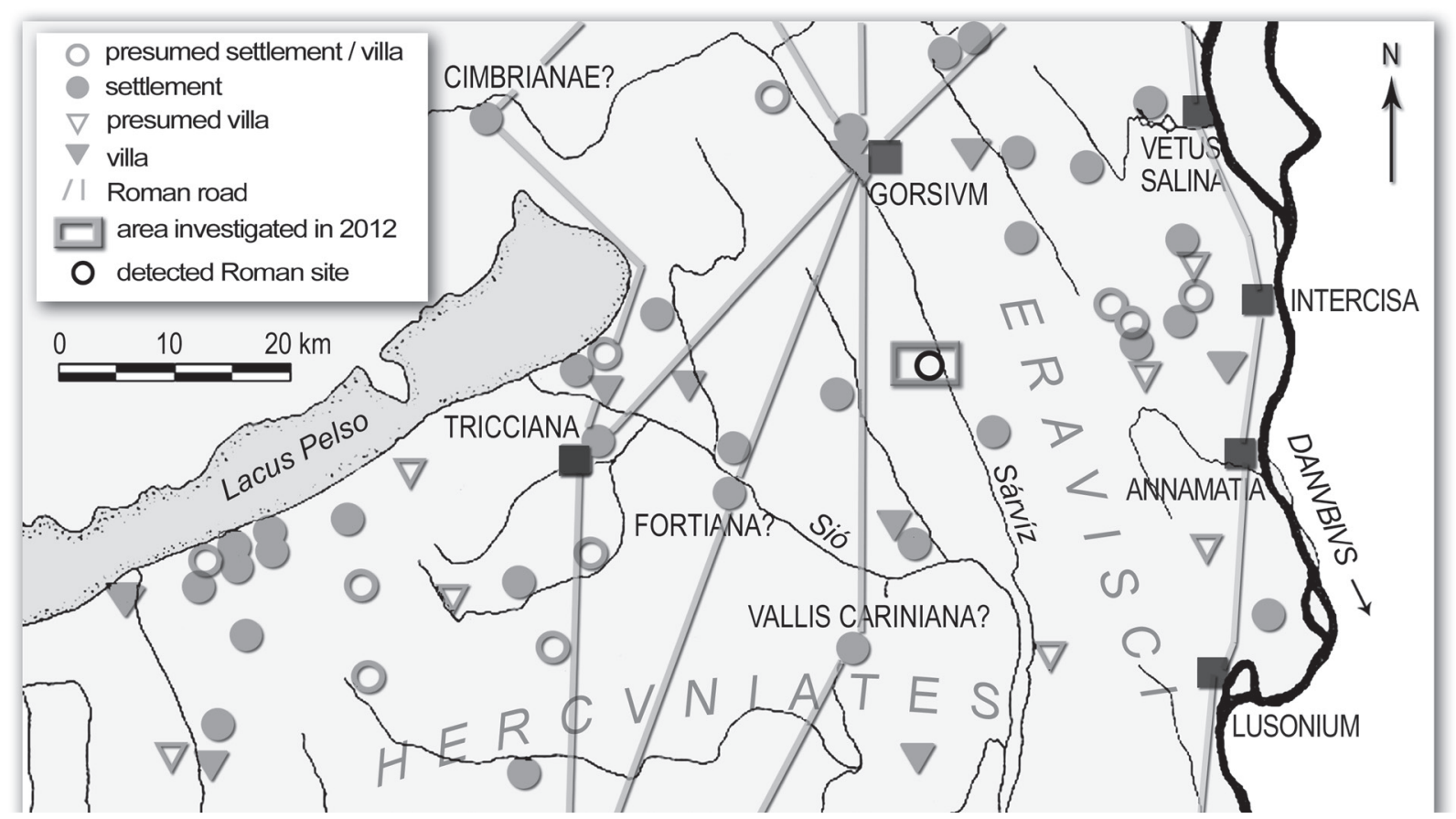

Fig. 2. The map of identified traces of Roman settlement to the south of the Lake Balaton and the location of the Roman site in the Sárvíz river valley (based on VISY 1994, Abb. 19.1)

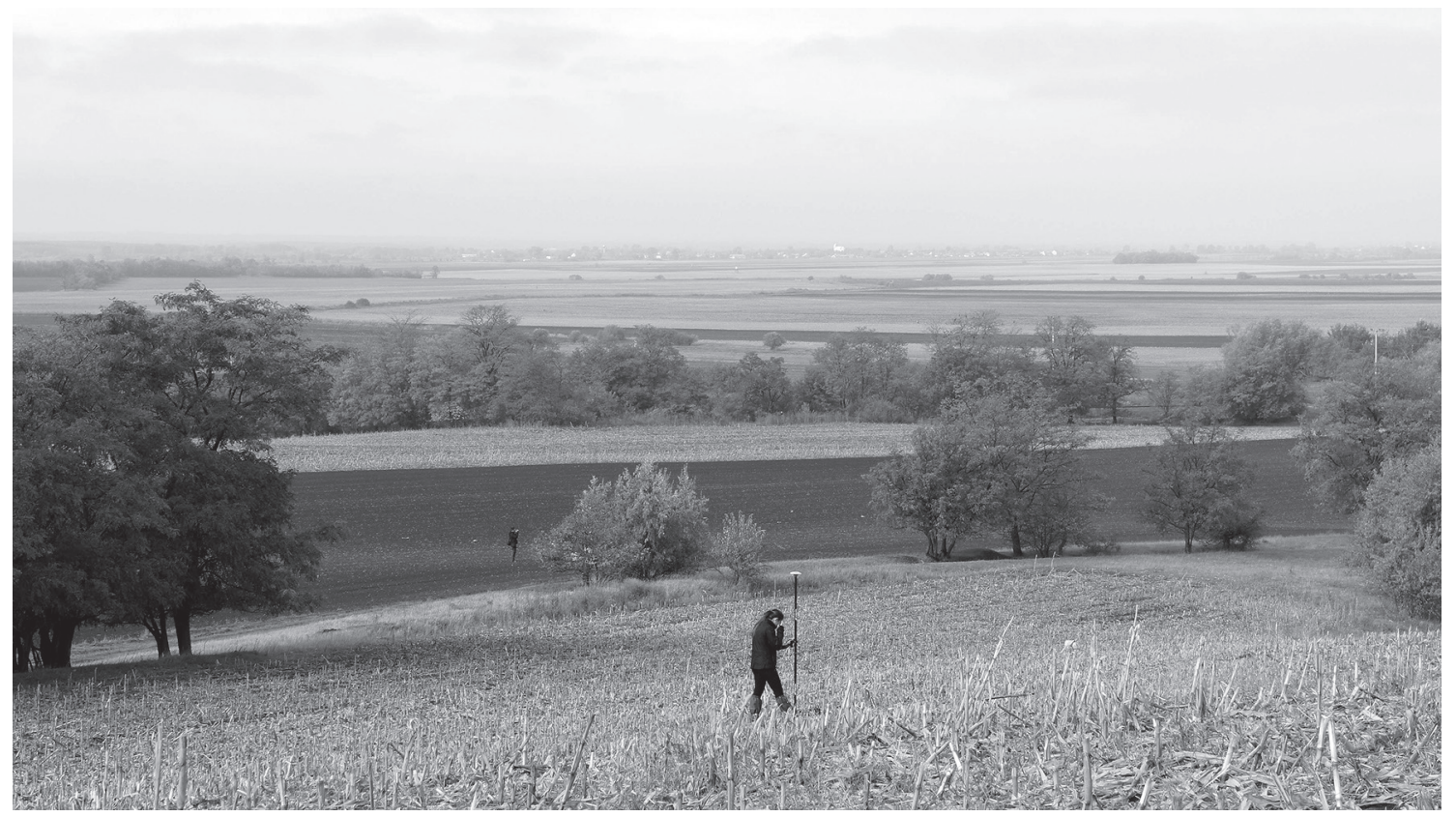

Fig. 3. Nagyhörcsökpuszta, Fejér county. The Sárvíz river valley and the view of the investigated site (photo by M. Stibrányi) 


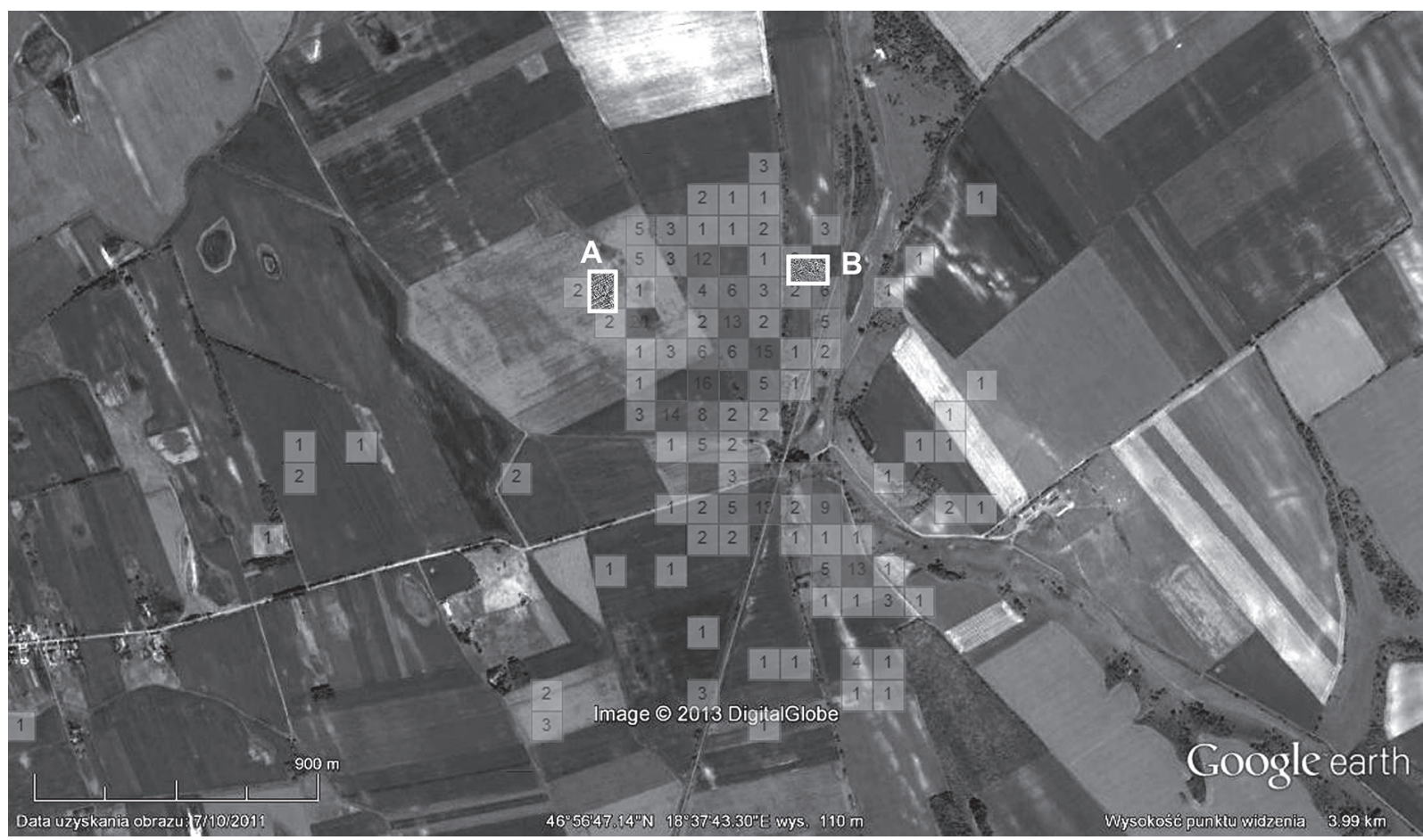

Fig. 4. The surveyed area in the Sárviz river valley. The squares mark one hectare polygons, where Roman pottery have been recorded; numbers - to their quantity; letters A and B mark the places of geophysical prospection (by G. Mesterházy, P. Wroniecki)

tates $^{5}$. Numerous magnetic anomalies visible on the image B may be traces of heating system (hypocaustum) or destruction by fire, though the rubble of roof tiles may give similar image (Fig. 5). It is difficult to state clearly whether the two places belong to separate estate buildings or buildings within one settlement (vicus). However, almost the same orientation of the two detected constructions placed at a distance of more than $500 \mathrm{~m}$ indicates that both of them must have been designated by the same axis, e.g. of the road plots (Fig. 6).

\section{POTTERY AND OTHER FINDS ${ }^{6}$}

Numerous vessel fragments densely spread here included kitchen ware, as well as table ware, both Pannonian and imported from the eastern and western part of the empire. During field survey 500 pieces of pottery and two fragments of tegulae were collected. The only non-ceramic find was a loaf-shaped limestone weight.

The majority of shards are not distinctive, small fragments which are not precisely datable, too. In general it can be dated from the $1^{\text {st }}$ to the $4^{\text {th }}$ century A.D. The large part of the material (401 shards, $80.2 \%$ ) constitutes household grey pottery (light gray to black). Its quality varies, mostly being coarse, gritty, rough-surfaced ware. The shards belonged to kitchen cooking and storage vessels (Fig. 7.7 - Fig. 8.8-9).

Two undecorated Pannonian grey slip ware with stamped decoration have been identified. Production of this type of pottery began at the end of the $1^{\text {st }} \mathrm{c}$. A.D., flourished in the middle of the $2^{\text {nd }}$, and after a small decline, had a new impetus of manufacture in the second quarter of the $3^{\text {rd }}$ c. A.D. ${ }^{7}$

One fragment was identified as an imitation of so-called 'Pompeian red plate' (Fig. 7.6). The earliest fragments of pottery of this type in Pannonia are dated to the end of the $1^{\text {st }}$ c. A.D., but only in the $2^{\text {nd }}$ became frequent. ${ }^{8}$

${ }^{5}$ Thomas 1964, 73ff. and fig. 40; Dinchev 1997, 45, fig. 31; MuLVIN 2002, 29 with figures

${ }^{6}$ Elaborated by Z. Kis (PhD cand.).
${ }^{7}$ PócZY 1957, 37.

${ }^{8}$ GABLER 1989, 476; GRÜNEWALD 1979, 41. 

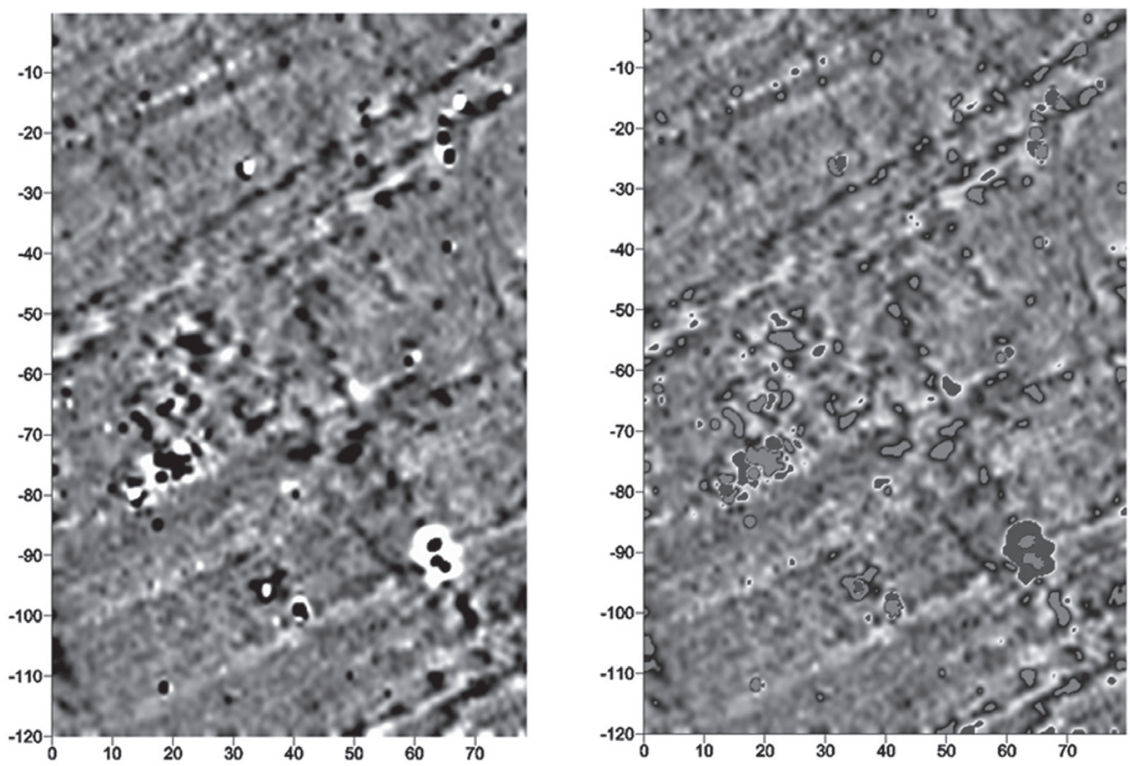

个

IMAGE A
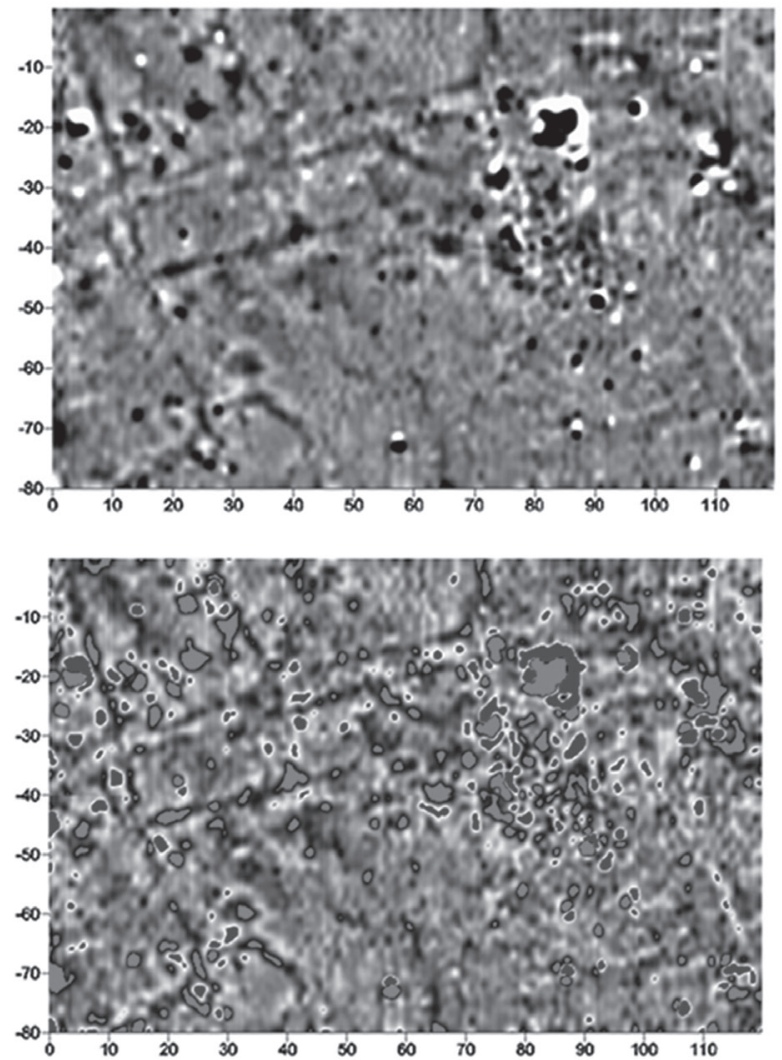

IMAGE B

Fig. 5. The Roman site in the Sárviz river valley. The results of magnetic prospection in places marked as A and B. Magnetic scale $-3 \mathrm{nT}$ (white) to $3 \mathrm{nT}$ (black) (by P. Wroniecki, M. Jaworski) 


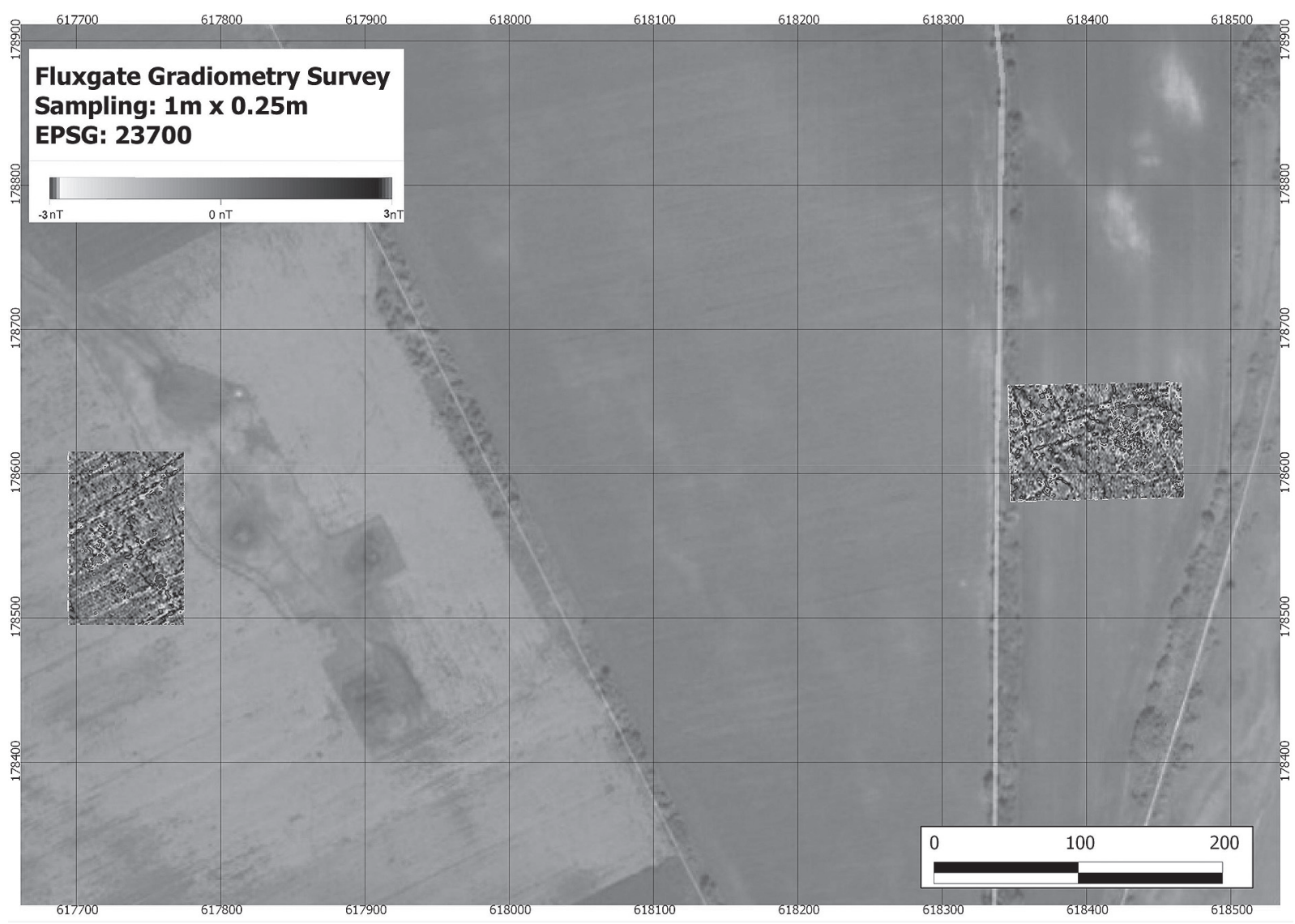

Fig. 6. The Roman site in the Sárviz river valley. A, B - the location of investigated places and the image obtained from geophysical prospection (by P. Wroniecki)

Tab. I. Morphological and typological analysis

\begin{tabular}{|c|c|c|c|c|c|c|}
\hline Ceramic types & Quantity (\%) & Body & Rim & Bottom & Lid & Handle \\
\hline household grey pottery & $401(80.2 \%)$ & 327 & 33 & 24 & 16 & 1 \\
\hline self-coloured pottery & $52(10.4 \%)$ & 49 & 3 & - & - & - \\
\hline red colour coated ware & $19(3.8 \%)$ & 17 & - & - & 2 & - \\
\hline storage jar & $7(1.4 \%)$ & 6 & 1 & - & - & - \\
\hline pottery with colour-coated horizontal bands & $7(1.4 \%)$ & 6 & 1 & - & - & - \\
\hline terra sigillata & $6(1.2 \%)$ & 5 & - & 1 & - & - \\
\hline marbled ware & $4(0.8 \%)$ & 3 & 1 & - & - & - \\
\hline Pannonian grey slip ware with stamped decoration & $2(0.4 \%)$ & 2 & - & - & - & - \\
\hline glazed mortarium & $1(0.2 \%)$ & 1 & - & - & - & - \\
\hline imitation of so-called 'Pompeian red plate' & $1(0.2 \%)$ & - & 1 & - & - & - \\
\hline
\end{tabular}




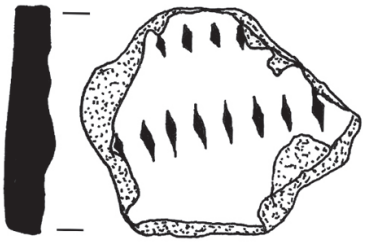

1.

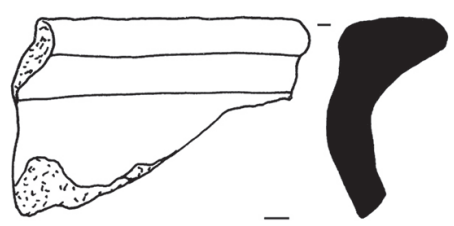

3.

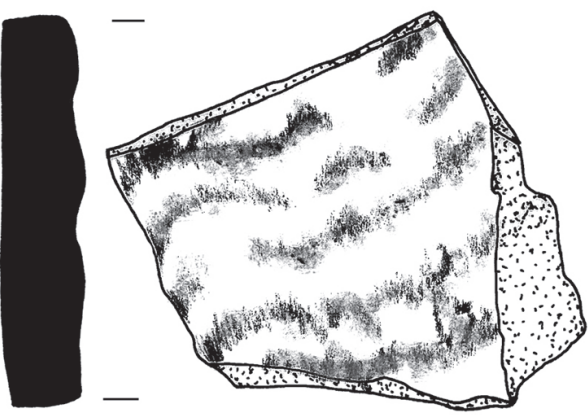

5.

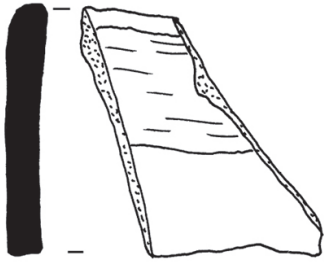

2.

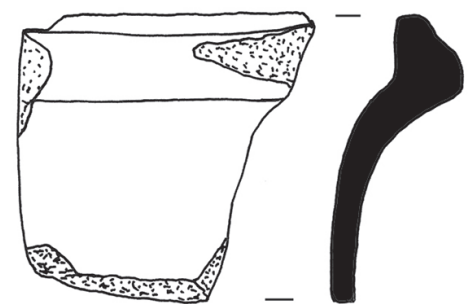

4.

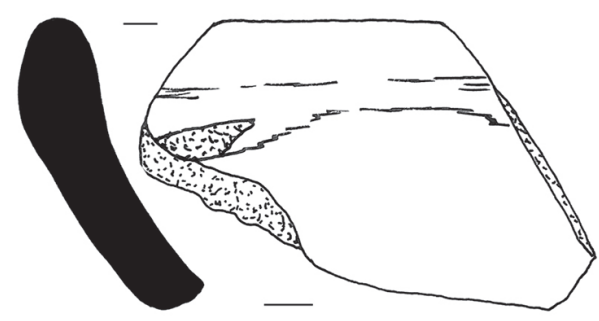

6.

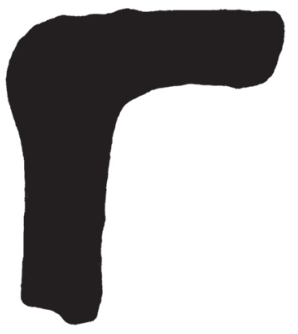

7.

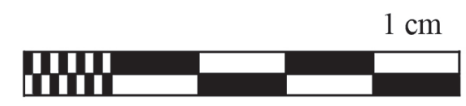

Fig. 7. 1-3. Fragments of pottery with colour-coated horizontal bands; 4. A self coloured jug rim; 5. Marbled ware fragment; 6. Fragment of so-called 'Pompeian red plate' imitation; 7. Fragment of household grey cooking pot with horizontal rim (M=1:1) (by Z. Kis) 


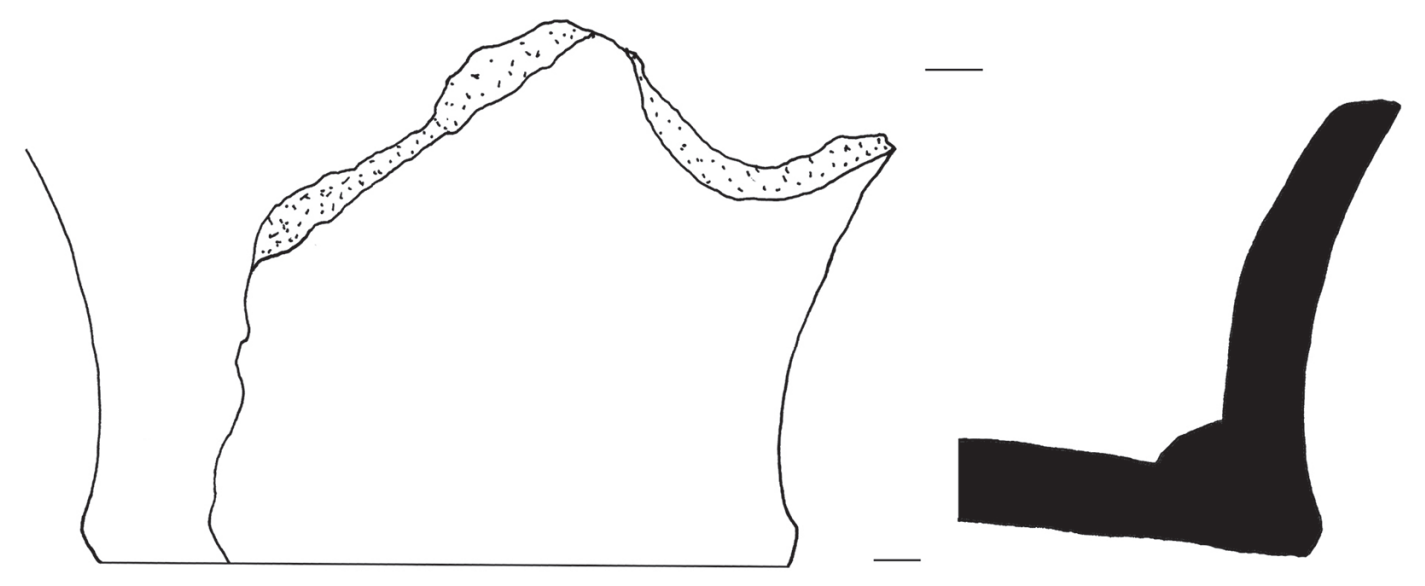

8.

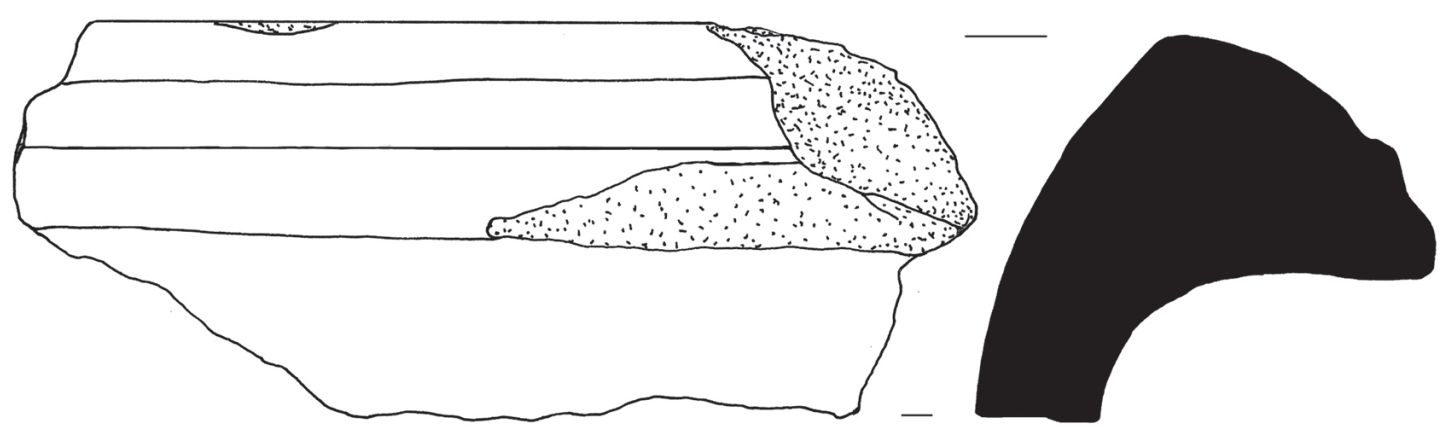

9.

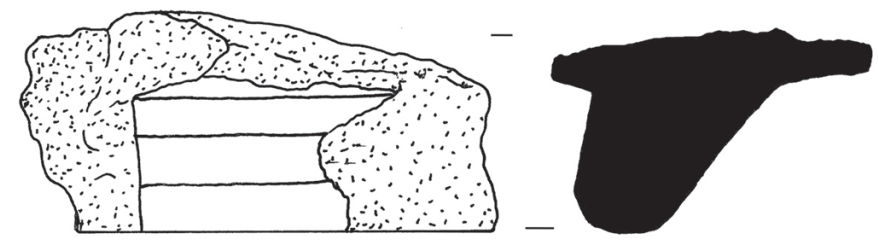

10.

\section{min}

Fig. 8. 8. Base fragment of household grey cooking pot;

9. Storage jar rim fragment; 10. Terra sigillata base fragment ( $M=1: 1)$ (by Z. Kis) 

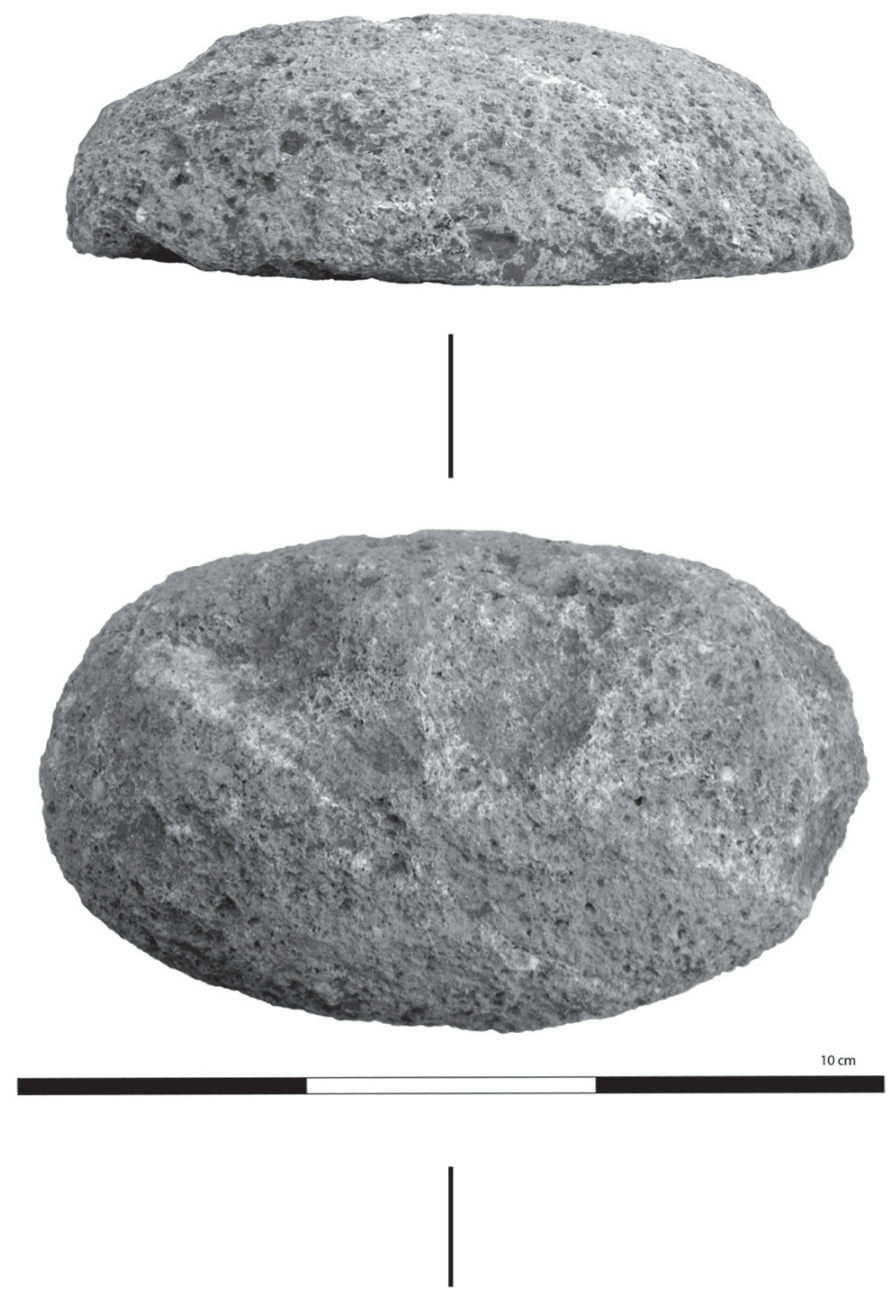

11.

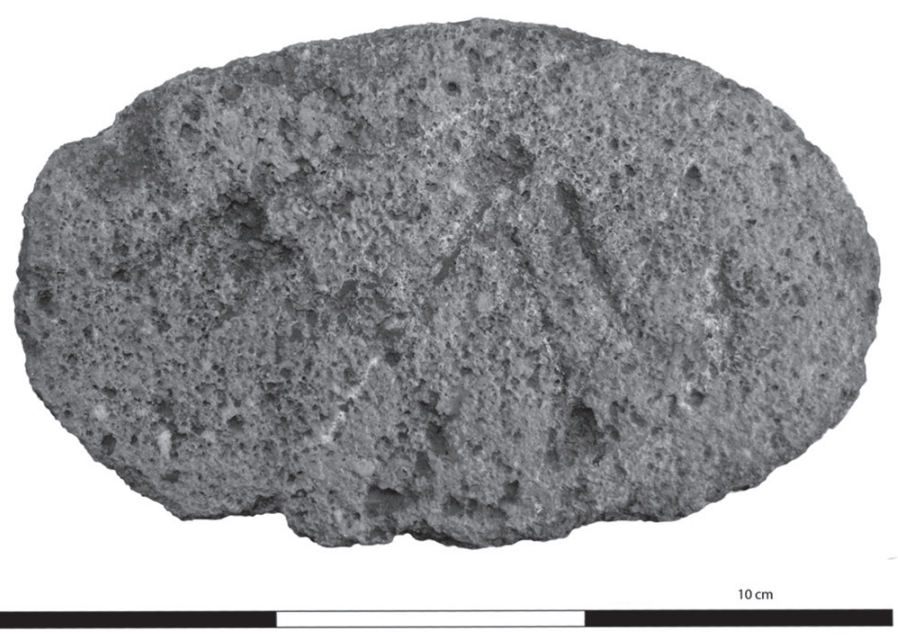

Fig. 9. Stone weight (?). (h: $9 \mathrm{~cm}, 1: 28 \mathrm{~cm}, \mathrm{w}: 17 \mathrm{~cm}, \mathrm{~W}: 4,85 \mathrm{~kg}$ ) (photo by Z. Kis) 
Marbled wares are represented by 4 shards (Fig. 7.5). This type of decoration appeared in the province in the $1^{\text {st }}$ century, but mostly prevailed in the Antonine Period. ${ }^{9}$ Local production was continued in Brigetio and in Aquincum still in the $3^{\text {rd }}$ c. A.D. ${ }^{10}$

One fragment was covered with a yellow-green glaze with gravel-plated inner area. It is probably a mortarium bowl fragment, which can be dated to the $3^{\text {rd }}-4^{\text {th }}$ c. A.D.

Pottery with colour-coated horizontal bands fragments (Fig. 7.1-3) started to be produced around the $1^{\text {st }}$ c. A.D. and lasted until the beginning of the $3^{\text {rd }} \mathrm{c}$.

Only 6 shards of terra sigillata have been identified. Five pieces are body fragments ( 3 undecorated, 2 relief decorated and one bottom, Fig. 8.10). One of them is decorated with a medallion. Another fragment is difficult to identify due to the fragmentary preservation.

A loaf-shaped stone - probably a stone weight - has been found on the site (Fig. 9.11). In Pannonia several stone weights have been uncovered, but their shape: oval, loaf, cylindrical ${ }^{11}$ or spherical ${ }^{12}$ differs from the piece collected during the surveys in the Sárvíz valley. On the top of the weight, there is a graved number XV, which indicates 15 Roman pounds (quindecim librae). The stone weights $4850 \mathrm{~g}$ which would be correspond or slightly less than expectable weight of 15 librae. It has a quite good preservation it has only some scrape by a plowshare. The estimated original weight is from 4781.25 to $4911.75 \mathrm{~g}$.

\section{ROMAN PROVINCIAL SETTLEMENT IN THE AREA OF SÁRBOGÁRD VILLAGE AND TO THE SOUTH OF THE LAKE BALATON}

The investigated is placed between two tribal territories of the Eraviscans and Hercuniates. ${ }^{13}$ During the Roman domination it was about $25 \mathrm{~km}$ south of the fort Gorsium (Tác), a military base garrisoned by a cavalry unit (ala Scubulorum) stationed from the middle of the $1^{\text {st }}$ century A.D., a significant civil town the beginning of the $2^{\text {nd }}$ century. ${ }^{14}$

Roman villae in Lower Pannonia are relatively well examined and published. ${ }^{15}$ So far, more than 100 sites of this kind have been located in the whole province, around 40 per cent of them being excavated. ${ }^{16}$ As it has been noted, probably all of them were built from the ground up, on the lands allotted to the veterans and Roman colonists. So far, no pre-Roman settlement has been unearthed to be converted into a villa. Pannonian estates dated to the $1^{\text {st }-2^{\text {nd }}} \mathrm{c}$. A.D. were mostly owned by Italic settlers or local aristocracy who, thanks to the loyalty to the new administration received Roman citizenship. ${ }^{17}$ It is agreed that veteran colonization of Lower Pannonian interior started in the $2^{\text {nd }}$ c. ${ }^{18}$ Estates of local aristocracy are rare, among others due to the fact that this group was not large in number. ${ }^{19}$ The Pannonian farm-house and villa estates range from $30 \times 40 \mathrm{~m}$ to about $200 \times 200 \mathrm{~m}$. Usually in plan they follow the pattern of Roman courtyard villa. ${ }^{20}$ Based on analysis of archaeological finds of tools, the backbone of farming was growing grain, followed by cultivation of vine, woodworking and animal breeding. Production focused on manufacture of bricks and ceramic tableware and metal products. ${ }^{21}$

The research on the rural settlements, especially during the transition period, is not so much advanced..$^{22}$ Generally the discussed area is considered to be poorly recognized with regard to both Roman villae and vici. ${ }^{23}$ More settlements have been recorded by the Sió river (Fig. 2) and the nearest Roman villa dated to the $2^{\text {nd }}-3^{\text {rd }} \mathrm{c}$. was

${ }^{9}$ BÓNIS 1942, 22; PÓCZy 1957, 42; GABLER 1989, 495.

${ }^{10}$ BÓNIS 1979, 155; PÓCZY 1956, 114.

${ }^{11}$ KuzsinszKy 1890, 97, No. 3, 5; 99, Nos. 14-16.

${ }^{12}$ KuZsinszky 1890, 97, No. 4; 99, No. 7; BorhySzÁmAdó 1997-1998, 110, Taf.11.1 a-b.

${ }^{13}$ GABLER 1982, 58-59, fig. 1; MÓCSY 1974, 53-55. On the territorial division and administration based on epigraphic evidence see P. Kovács: Territoria, pagi and vici in Pannonia. In: W. EcK-B. FEHER-P. KovÁcs (ed.): Studia epigraphica in memoriam Géza Alföldy. Bonn 2013, 131-154.

${ }^{14}$ Póczy 1980, 261-262.

15 Thomas 1964; Bíró 1974, 23-57; MócSY 1974; VISY 1994. On the recent non-invasive survey of Roman villas in Pannonia see M. SzABó: Using remote sensing and non-invasive archaeological methods in the research of Roman villas and the ancient landscape of Pannonia. In: Z. Czajlik-A. Bödőcs (eds.): Aerial Archaeology and Remote Sensing from the Baltic to the Adriatic. Selected Papers of the Annual Conference of the Aerial Archaeology Research Group, $13^{\text {th }}$ $15^{\text {th }}$ September 2012, Budapest, Hungary. Budapest 2013, 79-84.

${ }^{16}$ ThOMAs 1980, 276; VISY 1994.

${ }^{17}$ Mócsy 1974, 169

${ }^{18}$ VISY 1994, 427

${ }^{19}$ Mócsy 1974, 175.

${ }^{20}$ Thomas 1980, 292.

${ }^{21}$ Mócsy 1974, 170, fig. 32; Thomas 1980, 282.

${ }^{22}$ GABLER 1991, 424-425.

${ }^{23}$ Mócsy 1974, 169; VISY 1994, 429. 

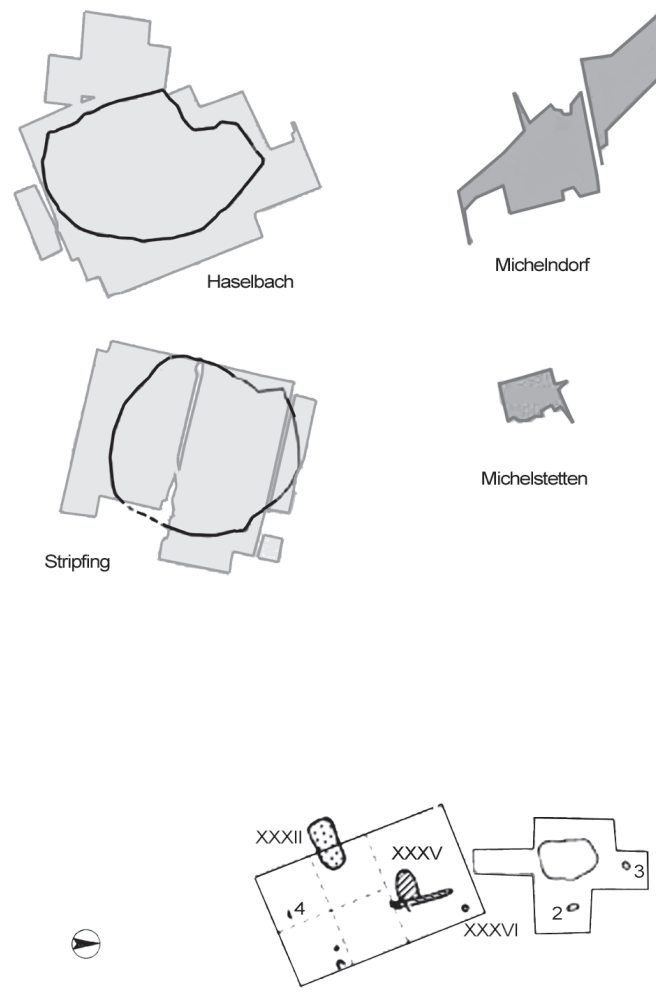

(2a) $20 \mathrm{~m}$

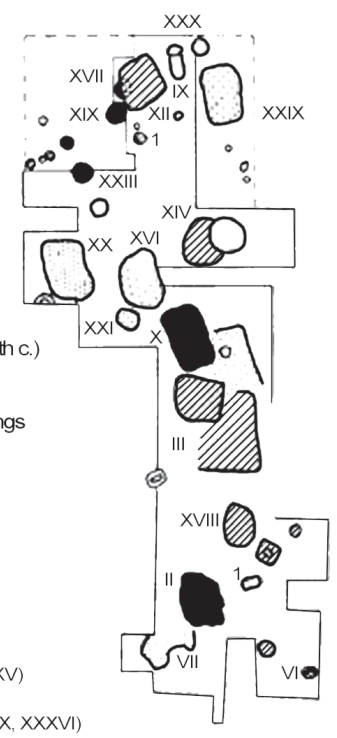

- features dated to the pre-Roman Iron Age

features dated to the pre-Roman Iron Age and the Early Roman Imperial period

features dated to the Roman Imperial Age

features dated to the Late Roman period (4th-5th c.)

7 trenches dug for the foundation of timber building

$\bigcirc$ post-house

(c) hearth, oven

The Roman numerals indicate:

- 'Grubenhous' (I, III, VII, X, XII, XVI, XVIII, XX, XXXII, XXXV)

- post-house (VI, XVI, XIX, XXI, XXIII, XXX, XXXVI)

- com-drier (?) or storage pits ( $\mathrm{VI}, \mathrm{XVI}, \mathrm{XIX}, \mathrm{XXI}, \mathrm{XXIII}, \mathrm{XXX}, \mathrm{XXXVI})$

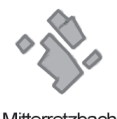

Mitterretzbach
(1)

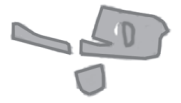

excavated area

Inzersdorf-Walpersdorf

prospected area

limits of settlement

assumed limits

of settlement

Göttlesbrunn
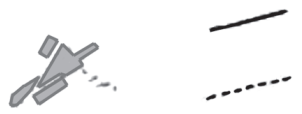

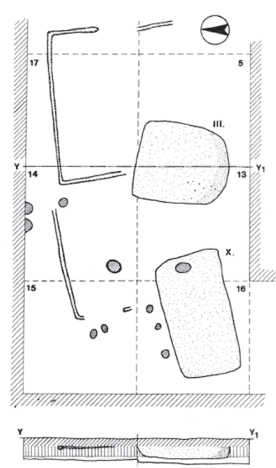

(2b)
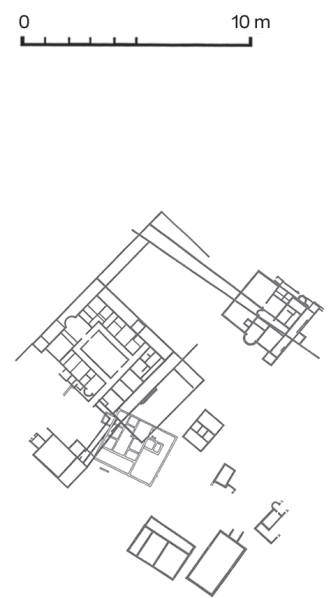

(3)

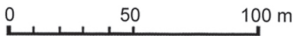

Fig. 10. The comparison of size and layout of selected pre-Roman and Roman rural settlements and estates in Pannonia.

1. Selected pre-Roman lowland settlements (after TREBSCHE 2014); 2. The pre-Roman settlement of Szakály.

The ground plan of the pit houses (after Transformation 2006); 3. The villa estate at Bakica (after PALÁGYI 2002) 
discovered near Enying-Hosszú Tó. ${ }^{24}$ From the surroundings of Sárbogárd comes a tombstone with inscription erected for a wealthy couple with Celtic names ${ }^{25}$ as well as a wagon burial discovered in the vicinity of Sárszentmiklós, considered to be an elite's grave related to the army. ${ }^{26}$ The nearest detected settlement (vicus) is at distance of ca. $10 \mathrm{~km}$ to the south, in the southern part of Sárbogárd-Sárszentmiklós village. ${ }^{27}$ Traces of local lowland settlement which have their continuity in the Roman period were recorded also south-west of the discussed area. ${ }^{28}$ The Fejér region is considered to be an area with burials in mounds, few in other parts of Pannonia. These are situated within the radius of $10-15 \mathrm{~km}$ around the discussed territory - near Sárbogárd, Nagylók and Káloz. ${ }^{29}$

\section{CONCLUSIONS}

Based on the above data, we can say with great probability that the discovered site belonged to one settlement, or to two separate units, but related to each other by layout and orientation. The spread of the archaeological finds would suggest the presence of a large settlement (vicus) or one or two villae. Of course, any interpretation must be treated as a one of possible hypotheses, since critical reviews met even excavated sites interpreted as villae..$^{30}$ The location of the site on the gently slope of the river valley is very characteristic for Roman villa estates, ${ }^{31}$ and the location of the discussed place fits to the observation made by L. Mulvin concerning the presence of large estates in the area south-west of Gorsium. ${ }^{32}$ If so, its owners would have originated from the local aristocracy, but this interpretation must remain very assumptive. On the other hand, the location of the site in the interior of the province, and finds discovered so far suggest that there is a certain probability that the site may have been a vicus inhabited by some local tribesmen.

\section{REFERENCES}

Bíró 1974

BóNIS 1942

BÓNIS 1979

BORHY-SZÁMADÓ 1997-1998

DINCHEV 1997

GABLER 1989

GABLER 1991

GABLER 1994

GRÜNEWALD 1979
GABLER 1982

= M. BíRó: Roman villas in Pannonia. ActaArchHung 26 (1974) 23-57.

= É. BóNIS: A császárkori edényművesség termékei Pannoniában (A terra szigillátákon kívül) (Die kaiserzeitliche Keramik aus Pannonien) I. DissPannII.20. Budapest 1942.

= É. BóNIS: Das Törpfervierter „Gerhát” von Brigetio. FolArch 30 (1979) 99-155.

= L. BORHY-E. SZÁMADÓ: Instrumenta Inscripta Latina aus Brigetio. Antaeus 24 (1997-1998) 93-115.

= V. Dinchev: Rimskite vili v dneshnata Bulgarska teritorija (Roman Villas in the Present-Day Bulgarian Lands). Sofia 1997.

= D. GABLER: Aspects of the development of Late Iron Age settlements into the Roman Period in Transdanubia. In: D. Gabler-E. Patek-I. Vörös: Studies in the Iron Age of Hungary. BAR IntSer144. Oxford 1982, 57-127.

= D. GABLER (ed.): The Roman Fort at Ács-Vaspuszta (Hungary) on the Danubian limes. BAR IntSer 531 Oxford, 1989.

= D. GABLER: The survival of late La Tène settlements in the Roman Period. In: V. A. Maxfield-M. J. Dobson (eds): Roman Frontier Studies 1989. Proceedings of the XVth International Congress of Roman Frontier Studies. Exeter 1991, 424-431.

= D. GABLER: Die ländliche Besiedlung Oberpannoniens. In: H. Bender-H. Wolff (Hrsg.): Ländliche Besiedlung und Landwirtschaft in den Rhein-Donau-Provinzen des Römischen Reiches. Vorträge eines Internationalen Kolloquiums vom 16.-21. April 1991 in Passau. 2. Passauer Universitätsschriften zur Archäologie. Espelkamp 1994, 377-419.

= M. GRÜNEWALD: Die Gefaßkeramik des Legionslagers von Carnuntum (Grabungen 1968-1974). RLiÖ 29. Wien 1979.

${ }^{24}$ VISY 1994, 442, no. 82.

${ }^{25}$ CIL III, $15151=$ RIU $1482=$ AE 2004, 1133, AD 100130. Place of discovery: Sárbogárd-Alsótöbörzsökpuszta, Fejér county. At present in Budapest - Magyar Nemzeti Múzeum (inv. No. 56.1900): Vindo Saturn/ini f(ilius) ann(orum) LX et Am/muta Mogetion/isf(ilia) an(norum) L h(ic) s(iti) s(unt) M(arcus) / Ulpius Brogimal rus gener t(itulum) $p$ (osuit).
${ }^{26}$ Dated to the second half of the $2^{\text {nd }}$ century. See: Mráv

${ }^{28}$ GABLER 1982, fig. 22, af. GABLER 1991.

${ }^{29}$ VISY 2003, 258, fig. 75.

${ }^{30}$ GABLER 1994, 377.

${ }^{31}$ Thomas 1980, 285.

${ }^{32}$ Mulvin 2002, 37. 
KUZSINSZKY 1890

MesterháZy 2013

MeSterháZY-STIBRÁNYi 2013

MócSY 1974

MrÁv 2011

Mulvin 2002

PALÁGyi 2002

PócZY 1956

PÓCZY 1957

PóCZY 1980

SOPRONI 1980

THOMAs 1964

THOMAS 1980

TOMAS-JAWORSKI 2013

Transformation

TREBSCHE 2014

VISY 1994

VISY 2003
$=$ B. KUZSINSZKY: Az aquincumi ásatások. 1882-1884 és 1889 [Excavations in Aquincum, 1882-1884 and 1889]. BudRég 2 (1890) 75-160.

= G. MESTERHÁZY: Regionális léptékü terepbejárás módszertani lehetőségeinek vizsgálata Magyarországon - Methodological possibilities of regional scale field walking in Hungary. ArchÉrt 138 (2013) in press.

= G. MeSTERHÁZY-M. StiBRÁNYi: Non-destructive archaeological investigations in the Sárvíz valley. Hungarian Archaeology 1-4 2013 (e-journal available at http://www.hungarianarchaeology.hu/)

= A. Mócsy: Pannonia and Upper Moesia. A History of the Middle Danube. Provinces of the Roman Empire. London-Boston, 1974.

= Zs. MRÁv: Auf Reisewagen appliezierte „Benefiziarierabzeichen” aus zwei nordostpannischen Wagengräbern. Die eraviskische Stammeselite im Dienste Roms. ArchÉrt 136 (2011) 21-61.

= L. Mulvin: Late Roman Villas in the Danube-Balkan Region. BAR IntSer 1064. Oxford 2002.

= S. PALÁGYI: Előzetes jelentés a balácai villagazdaság III-as és XIV-es épületének feltárásáról. Balácai Közlemények 6 (2001) [2002] 7-60.

= K. Póczy: Die Törpferwerkstätten von Aquincum. ActaArchHung 7 (1956) 73-138.

= K. Póczy: Keramik. In: M. R. Alföldi et al. (Hrsg.): Intercisa II. (Dunapentele). Geschichte der Stadt in der Römerzeit. ArchHung 36. Budapest 1957, 29-139.

= K. PócZY: Pannonian cities. In: A. Lengyel-G. T. B. Radan (eds): The Archaeology of Roman Pannonia. Lexington-Budapest 1980, 239-274.

= S. Soproni: Roads. In: A. Lengyel-G. T. B. Radan (eds): The Archaeology of Roman Pannonia. Lexington-Budapest 1980, 207-217.

= E. Thomas: Römische Villen in Pannonien. Beiträge zur pannonischen Siedlungsgeschichte. Budapest 1964.

= E. Thomas: Villa settlements. In: A. Lengyel-G. T. B. Radan (eds.): The Archaeology of Roman Pannonia. Lexington-Budapest 1980, 275-322.

= A. TOMAS-M. JAWORSKI: Non-destructive archaeological investigations in the Sárviz river valley (Hungary). Światowit 10 (51)/A (2012) [2013] 171-176.

$=$ Pannonia. Emergence of vici. In: Transformation The Emergence of Common Culture in the Northern Provinces of the Roman Empire from Britain to the Black Sea up to 212 AD. (http://www.rgzm. de/transformation/home/frames.htm).

= P. TREBSCHE: Size and economic structure of La Tenè period lowland settlements in the Austrian Danube region. In: Produktion - Distribution - Ökonomie. Siedlungs- und Wirtschaftsmuster der Latènezeit. Akten des internationalen Kolloquiums in Otzenhausen, 28.-30. Oktober 2011. Hrsg.: S. Hornung. Bonn 2014, 341-375.

= Zs. VISY: Die ländliche Besiedlung und Landwirtschaft in Niederpannonien. In: H. Bender-H. Wolff (Hrsg.): Ländliche Besiedlung und Landwirtschaft in den Rhein-Donau-Provinzen des Römischen Reiches. Vorträge eines Internationalen Kolloquiums vom 16.-21. April 1991 in Passau. I. Esselkamp 1994, 421-449.

= Zs. VISY (ed.): Magyar régészet az ezredfordulón (Hungarian Archaeology at the Turn of the Millennium). Budapest, 2003. 